\title{
Metal ion complexes of nucleoside phosphorothioates reflecting the ambivalent properties of lead(II) ${ }^{\ddagger}$
}

Astrid Sigel, ${ }^{a}$ Bert P. Operschall, ${ }^{a}$ Roland K. O. Sigel*b and Helmut Sigel*a

Contents

Abstract

1 Some historical remarks including the toxicity of lead

2 The affinity of lead(II) towards various binding sites

3 Complexes of phosphorothioates with lead(II) and other metal ions

4 Effect of a non-bridging $S$ atom in the phosphate diester linkage on complex stability

5 Conclusions including the role of the lead(II) lone pair

6 A caveat

Acknowledgments

Notes and references

a Department of Chemistry, Inorganic Chemistry, University of Basel, Spitalstrasse 51, CH-4056 Basel, Switzerland.E-mail: helmut.sigel@unibas.ch; Fax: +41 612071017

b Department of Chemistry, University of Zürich, Winterthurerstrasse 190, CH-8057 Zürich, Switzerland. E-mail: roland.sigel@chem.uzh.ch; Fax: +41 446356802 


\section{(Abstract)}

This Perspective outlines the coordinating properties of lead(II), to some extent in comparison with related metal ions like $\mathrm{Ca}^{2+}, \mathrm{Zn}^{2+}$ or $\mathrm{Cd}^{2+}$. It is worth to note that the affinity of $\mathrm{Pb}^{2+}$ towards phosphate residues corresponds to that of $\mathrm{Cu}^{2+}$. Furthermore, the binding tendency of $\mathrm{Pb}^{2+}$ towards thiophosphate groups as present in methyl thiophosphate (MeOPS ${ }^{2-}$ ) or uridine 5'O-thiomonophosphate (UMPS ${ }^{2-}$ ) is compared with that of the parent ligands, that is, methyl phosphate $\left(\mathrm{CH}_{3} \mathrm{OPO}_{3}^{2-}\right)$ and uridine 5 '-monophosphate $\left(\mathrm{UMP}^{2-}\right)$. The replacement of an $\mathrm{O}$ by a $\mathrm{S}$ atom makes the monoprotonated thiophosphate group considerably more acidic [compared to $\mathrm{ROP}(\mathrm{O}) \overline{2}(\mathrm{OH})]$, but at the same time its affinity for $\mathrm{Pb}^{2+}$ increases tremendously: more than $99 \%$ of $\mathrm{Pb}^{2+}$ is S-bound. This is very different if the coordinating properties of uridylyl-(5' $\left.\rightarrow 3^{\prime}\right)$ [5']-uridylate $\left(\mathrm{pUpU}^{3-}\right)$ and P-thiouridylyl-(5' $\left.\rightarrow 3^{\prime}\right)-\left[5^{\prime}\right]$-uridylate $\left(\mathrm{pUp}_{(\mathrm{s})} \mathrm{U}^{3-}\right)$ are compared: The phosphate-coordinated $\mathrm{Pb}^{2+}$ forms a 10-membered chelate with one of the two terminal $\mathrm{O}$ atoms of the phosphodiester linkage which reaches a formation degree of about $90 \%$ in $\mathrm{Pb}(\mathrm{pUpU})^{-}$. However, in $\mathrm{Pb}\left(\mathrm{pUp}_{(\mathrm{S})} \mathrm{U}\right)^{-}$the formation degree of the chelate is reduced to about half in accord with the fact that now only one terminal $\mathrm{O}$ atom is available in the thiophosphate diester bridge, that is, $\mathrm{Pb}^{2+}$ coordinates to this $\mathrm{O}$ showing no affinity for $\mathrm{S}$ in $\mathrm{ROP}(\mathrm{O})(\mathrm{S})^{-} \mathrm{OR}$ '. These observations are ascribed to the properties of the $\mathrm{Pb}^{2+}$ lone pair which shapes the $\mathrm{Pb}^{2+}$ coordination sphere; its role is discussed further in this Perspective and a caveat is made regarding $\mathrm{Pb}^{2+}$ binding to a thiophosphate diester linkage. 


\section{Some historical remarks including the toxicity of lead}

The metal lead is well known to mankind for thousands of years. The British museum displays a nearly 6000 year-old figure made from lead, it was known to the early Egyptians and Hebrews, and was mined in Spain as early as 2000 B.C. ${ }^{1}$

The toxicity of lead was recognized already by Greek and Arab scholars; ${ }^{1-3}$ its acute and chronic effects have been reviewed. ${ }^{4-6}$ Lead produces adverse effects in mammals, e.g., it acts on the central and peripheral nervous systems, ${ }^{7-9}$ it affects the genetic and reproductive machinery, ${ }^{8-11}$ and it interferes with the metabolism of other metal ions like iron, copper, zinc or calcium. ${ }^{12,13}$ For example, $\mathrm{Pb}^{2+}$ replaces $\mathrm{Ca}^{2+}$ in bones ${ }^{4}$ indicating a chemical relationship, ${ }^{12}$ which is in accord with the similarity of the radii of $\mathrm{Ca}(\mathrm{II})$ and $\mathrm{Pb}(\mathrm{II})^{12,13}$ and their relative affinity for O-donor sites. ${ }^{3,12}$ Indeed, about 95\% of the body burden of lead is stored in bones.,14 Due to the indicated negative effects, lead was much studied in the $1980 \mathrm{~s},{ }^{1-4}$ but the interest ceased somewhat due to the fact that leaded gasoline was banned. ${ }^{15,16}$

However, recently, due to the above mentioned adverse effects of lead, its again increasing use, ${ }^{17}$ and the recognition that lead(II) is distributed all over the globe, ${ }^{18-21}$ it moved back into the center of research ${ }^{5,20}$ because already low concentrations leave their marks, ${ }^{22}$ and no safe exposure limit according to the US Environmental Protection Agency (EPA) can be defined. ${ }^{20}$ Consequently, biomonitoring of lead has become an important issue $\mathrm{e}^{23-25}$ and much efforts are presently spent on its detection at low levels. ${ }^{26-30}$ Nucleic acid aptamers and DNAzymes are thereby prominent ways to detect $\mathrm{Pb}(\mathrm{II})$ at low concentrations. ${ }^{27,28}$ Their sensitivity towards $\mathrm{Pb}(\mathrm{II})$ is determined by the intrinsic coordination properties of this ion compared to other divalent metal ions, which we summarize in this Perspective.

\section{The affinity of lead(II) towards various binding sites}

The affinity of $\mathrm{Pb}^{2+}$ towards oxygen-binding sites corresponds approximately ${ }^{12,13,31}$ to that of $\mathrm{Cu}^{2+}$ as is nicely seen from the Irving-Williams sequence-type plots ${ }^{32,33}$ shown in Figure 1 for 
various nucleotides. ${ }^{34-40}$ This observation is confirmed by the following stability constants which refer to metal ion $\left(\mathrm{M}^{2+}\right)$ complexes of phosphate monoesters or phosphonates ( $\left.\mathrm{R}^{\mathrm{PO}}{ }_{3}^{2-}\right)(\mathrm{Eq} .1)$ and the stability of these complexes also depends on the acid-base properties (Eq. 2) of the phosph(on)ate ligands (vide infra).

$$
\begin{aligned}
& \mathrm{M}^{2+}+\mathrm{R}^{-} \mathrm{PO}_{3}^{2-} \rightleftharpoons \mathrm{M}\left(\mathrm{R}-\mathrm{PO}_{3}\right) \\
& K_{\mathbf{M}\left(\mathrm{R}-\mathrm{PO}_{3}\right)}^{\mathrm{M}}=\left[\mathrm{M}\left(\mathrm{R}-\mathrm{PO}_{3}\right)\right] /\left(\left[\mathrm{M}^{2+}\right]\left[\mathrm{R}-\mathrm{PO}_{3}^{2-}\right]\right) \\
& \mathrm{H}\left(\mathrm{R}-\mathrm{PO}_{3}\right)^{-} \rightleftharpoons \mathrm{R}-\mathrm{PO}_{3}^{2-}+\mathrm{H}^{+} \\
& K_{\mathrm{H}\left(\mathrm{R}-\mathrm{PO}_{3}\right)}^{\mathrm{H}}=\left[\mathrm{R}^{-\mathrm{PO}_{3}^{2-}}\right]\left[\mathrm{H}^{+}\right] /\left[\mathrm{H}\left(\mathrm{R}-\mathrm{PO}_{3}\right)^{-}\right]
\end{aligned}
$$

To the acidity constant $\mathrm{p} K_{\mathrm{H}\left(\mathrm{R}-\mathrm{PO}_{3}\right)}^{\mathrm{H}}=6.20$ refer the stability constants $\log K_{\mathrm{Cu}\left(\mathrm{R}-\mathrm{PO}_{3}\right)}^{\mathrm{Cu}}=2.87 \pm$ 0.06 and $\log K_{\mathbf{P b}\left(\mathbf{R}-\mathrm{PO}_{3}\right)}^{\mathbf{P b}}=2.93 \pm 0.08$ for the $\mathrm{Cu}^{2+}$ and $\mathrm{Pb}^{2+}$ complexes, respectively. ${ }^{13,31}$ These constants are evidently identical within their error limits.

This observation contrasts with the one made for N-donor sites, ${ }^{31}$ where the affinity of $\mathrm{Pb}^{2+}$ corresponds approximately to the one of $\mathrm{Mn}^{2+}$ and $\mathrm{Fe}^{2+} \cdot{ }^{13}$ This means that the affinity of $\mathrm{Pb}^{2+}$ towards $\mathrm{N}$ sites (ammonia, imidazole) is relatively small, which is in accord ${ }^{13}$ with the "Stability Ruler" of Martin. 2,12,41,42 Furthermore, a detailed assessment of the $\mathrm{Pb}^{2+}$ affinities towards the individual coordinating atoms in nucleotides is also available. ${ }^{43}$ It is further worthwhile to mention in the context of the relationship between $\mathrm{Cu}^{2+}$ and $\mathrm{Pb}^{2+}$, that the hydrolysis values for the two hydrated metal ions are very similar, that is, $\mathrm{p} K_{\mathrm{Cu}\left(\mathrm{H}_{2} \mathrm{O}\right)_{\mathbf{n}}}^{\mathrm{H}}=7.53$ and $\mathrm{p}_{\mathrm{Pb}_{\left(\mathrm{H}_{2} \mathrm{O}\right)_{\mathbf{n}}}^{\mathrm{H}}}^{\mathrm{H}}=$ 7.78. ${ }^{13,44,45}$

Both ions, i.e., $\mathrm{Pb}^{2+}$ and $\mathrm{Cu}^{2+}$, also have at least under certain conditions a high affinity towards sulfur sites as follows from the large solubility products of $\mathrm{CuS}$ and $\mathrm{PbS} .{ }^{13}$ It is thus not surprising that phosphorothioates, in which a terminal phosphate $\mathrm{O}$ is replaced by a $\mathrm{S}$ atom giving the $-\mathrm{PO}(\mathrm{O}){ }_{2}(\mathrm{~S})^{-}$residue, have become popular. Indeed, they are widely applied, ${ }^{13,46-48}$ e.g., as therapeutics, ${ }^{49,50}$ small interfering RNAs (siRNA), ${ }^{51,52}$ and as tools to study the chemistry of ribozymes. ${ }^{46,47,53,54}$ Sometimes nucleotide phosphorothioates are addressed in the literature as thionucleotides. This is confusing ${ }^{13}$ and should not be done because this expression is reserved for those nucleotides in which in the nucleobase residue a carbonyl $\mathrm{O}$ is replaced by a $\mathrm{S}$ atom. ${ }^{55}$ The latter compounds also occur in Nature, ${ }^{56,57}$ like, e.g., the nucleoside 2-thiocytidine. 
In this Perspective we will focus on the affinity of lead(II) towards a terminal phosphorothioate group in a nucleoside phosphorothioate on the one hand (Section 3) and the affinity of a phosphodiester bridge on the other, in which one of the two terminal $\mathrm{O}$ atoms has been replaced by a $\mathrm{S}$ atom, like in $P$-thiouridylyl-(5' $\left.\rightarrow 3^{\prime}\right)$-[5']-uridylate $\left(\mathrm{pUp}_{(\mathrm{S})} \mathrm{U}^{3-}\right)$ (Section 4$)$.

\section{Complexes of phosphorothioates with lead(II) and other metal ions}

From the three thio derivatives seen in Figure $2,{ }^{58-62}$ we will first consider methyl thiophosphate and uridine 5'-O-thiomonophosphate (UMPS ${ }^{2-}$ ) because evidently neither the methyl group nor the uracil residue will participate in metal ion coordination; ${ }^{63,64}$ hence, the thiophosphate group will dictate the metal ion-binding properties of these two ligands (L). It may be added that in the protonated thiophosphate group the proton is located at one of the terminal oxygen atoms, $-\mathrm{OP}(\mathrm{S})(\mathrm{O})(\mathrm{OH})^{-} \cdot{ }^{65}$ However, in the deprotonated $-\mathrm{OP}(\mathrm{S})(\mathrm{O}){ }_{2}^{2-}$ moiety one of the two negative charges is located at the sulfur atom. ${ }^{65-67}$

\section{insert Figure 2 close to here insert Table 1 close to here}

The constants assembled ${ }^{68}$ in Table 1 allow a comparison of the properties of a phosphorothioate versus a phosphate group. It is evident that the replacement of one of the three terminal $\mathrm{O}$ atoms by a $\mathrm{S}$ atom in the phosphate residue acidifies the monoprotonated compounds by about $1.4 \mathrm{pK}$ units. In contrast to this decrease in basicity is the significantly enhanced stability of the $\mathrm{Pb}^{2+}$ complexes with the thio derivatives; this stability increase amounts to about $1.8 \log$ units and proves the participation of the $\mathrm{S}$ atom in $\mathrm{Pb}^{2+}$ coordination.

insert Figure 3 close to here

The enhanced complex stability of the $\mathrm{Pb}^{2+}$ complexes is even better seen in Figure 3, ${ }^{69-71}$ where the (thio)-phosphate systems of $\mathrm{Ca}^{2+}, \mathrm{Zn}^{2+}$, and $\mathrm{Cd}^{2+}$ are also considered. From the $\log K$ versus $\mathrm{p} K_{\mathrm{a}}$ plots for simple phosphate and phosphonate ligands, which fit a straight line, ${ }^{64}$ it is evident that the stability constants of the $\mathrm{Ca}^{2+}, \mathrm{Zn}^{2+}, \mathrm{Cd}^{2+}$, and $\mathrm{Pb}^{2+}$ complexes with $\mathrm{UMP}^{2-}$ or $\mathrm{MeOP}^{2-}$ fit on these straight lines meaning that the residue $\mathrm{R}$ in these $\mathrm{M}\left(\mathrm{R}-\mathrm{PO}_{3}\right)$ complexes does 
not have any effect on complex stability. Also with the two thiophosphates and $\mathrm{Ca}^{2+}$ there is no alteration observed, that is, the data points for $\mathrm{Ca}(\mathrm{MeOPS})$ and $\mathrm{Ca}(\mathrm{UMPS})$ fit on the straight reference line. On the contrary, the corresponding complexes of $\mathrm{Pb}^{2+}$ and $\mathrm{Cd}^{2+}$ experience a tremendous stability enhancement of about 2.4 log units, which clearly needs to be attributed to the $\mathrm{S}$ atom in the $-\mathrm{OP}(\mathrm{O}){ }_{2}{ }_{2}(\mathrm{~S})^{-}$residue. The stability enhancement for the $\mathrm{Zn}^{2+}$ complexes is with about $0.6 \log$ unit of a more modest size; ${ }^{69}$ the fact that the data points for $\mathrm{Zn}(\mathrm{MeOPS})$ and $\mathrm{Zn}(\mathrm{UMPS})$ fall on the $\mathrm{Pb}^{2+}$ straight-reference line is by chance.

The indicated stability enhancements for the thio derivatives (PS) can be expressed unequivocally by $\log \Delta_{\mathrm{M} / \mathrm{PS}}$ which is defined in Equation (3) ${ }^{13,69}$

$$
\log \Delta_{\mathrm{M} / \mathrm{PS}}=\log K_{\mathbf{M}(\mathrm{PS})_{\exp }}^{\mathbf{M}}-\log K_{\mathbf{M}(\mathbf{P S})_{\text {calc }}}^{\mathbf{M}}
$$

where the first term on the right hand side is experimentally measured and the second one reflects the intercept of the vertical dotted lines with the reference lines in Figure 3. This intercept is defined by the $\mathrm{p} K_{\mathrm{a}}$ value of the monoprotonated ligand, i.e., $\mathrm{p} K_{\mathrm{H}(\mathbf{P S})}^{\mathrm{H}}$.

insert Table 2 close to here

The corresponding quantitative evaluation is summarized in Table 2. ${ }^{68,69,72}$ In accord with Figure $3 \log \Delta_{\mathrm{M} / \mathrm{PS}}$ is zero within its error limit for the $\mathrm{Ca}^{2+}$ complexes, whereas for the complexes of $\mathrm{Zn}^{2+}, \mathrm{Cd}^{2+}$, and $\mathrm{Pb}^{2+}$ the stability enhancements expected on the basis of the estimates from Figure 3 are observed. The complexes of the three thio derivatives, MeOPS ${ }^{2-}$, $\mathrm{UMPS}^{2-}$, and $\mathrm{AMPS}^{2-}$ (Fig. 2) behave identically within the error limits allowing thus the calculation of an averaged stability enhancement. Clearly, as indicated already above, these stability enhancements reflect the extent of the thio coordination of $\mathrm{M}^{2+}$. This means, one has to consider the intramolecular Equilibrium (4),

$$
\mathrm{PO} \cdot \mathrm{M} \stackrel{K_{\mathrm{I}}}{\rightleftharpoons} \mathrm{PS} \cdot \mathrm{M}
$$

where PO $\mathbf{M}$ represents the O-coordinated isomer and PS $\mathbf{M}$ the corresponding S-coordinated one. The connected intramolecular and dimensionless equilibrium constant, $K_{\mathrm{I}}$ (or ratio $R$ ) is defined in Equation (5): 


$$
\begin{aligned}
& K_{\mathrm{I}}=\frac{[\mathrm{PS} \cdot \mathrm{M}]}{[\mathrm{PO} \cdot \mathrm{M}]}=\frac{K_{\mathrm{M}(\mathrm{PS})_{\exp }}^{\mathrm{M}}}{K_{\mathrm{M}(\mathrm{PS})_{\mathrm{cal}}}^{\mathrm{M}}}-1=10^{\log A_{\mathrm{M} / \mathrm{PS}}}-1 \\
& \% \mathrm{PS} \cdot \mathrm{M}=100 \cdot K_{\mathrm{I}} /\left(1+K_{\mathrm{I}}\right)
\end{aligned}
$$

By following previous routes ${ }^{69,72}$ the formation degrees (in percentages) of the sulfur-bound isomers can be calculated according to Equation (6) and these results are given in the terminating column of Table 2 . As expected, no PS· Ca isomers are formed. However, PS•Pb and PS•Cd form to nearly $100 \%$. This is different for the $\mathrm{Zn}^{2+}$ complexes where about $75 \%$ occur as the PS $\cdot \mathrm{Zn}$ isomer being in equilibrium with about $25 \%$ of the oxygen-coordinated $\mathrm{PO} \cdot \mathrm{Zn}$ isomer.

Among others the following conclusions can be drawn: For $\mathrm{Ca}^{2+}$ and the other alkaline earth ions $^{69,72}$ the same affinity towards $-\mathrm{PO}(\mathrm{O}) \overline{2}_{2}^{-}(\mathrm{S})^{-}$and $\mathrm{OP}(\mathrm{O})_{3}^{2-}$ residues is observed and this justifies also the application of the straight-line plots based on $\mathrm{R}^{-\mathrm{PO}_{3}^{2-}}$ complexes for the other metal ions considered. From the data given in Table 2 (column 2) it follows that the uracil residue in the M(UMPS) complexes has no effect and does not participate in complex formation. Indeed, this is in accord with the preceding discussion in the context of the straight reference lines (Fig. 3). It may be added that the given formation degrees for the PS•M species of the various metal ions reflect the solubility products ${ }^{13}$ which increase in the order $\mathrm{ZnS}<\mathrm{CdS}<\mathrm{PbS}$, PbS being the least soluble of these sulfides (for further more detailed comparisons see Ref. 72).

\section{Effect of a non-bridging $S$ atom in the phosphate diester linkage on complex stability}

Next we consider the metal ion affinity of a phosphodiester bridge in which one of the two terminal $\mathrm{O}$ atoms is replaced by a $\mathrm{S}$ atom (Fig. 4). In Figure 5 the reference lines for the $\mathrm{Pb}^{2+}$, $\mathrm{Cd}^{2+}, \mathrm{Mg}^{2+} / \mathrm{H}^{+} / \mathrm{R}_{-} \mathrm{PO}_{3}^{2-}$ systems, ${ }^{63,64,68}$ analogous to those seen in Figure 3, are plotted plus the data points for the $\mathrm{Pb}^{2+}, \mathrm{Cd}^{2+}$, and $\mathrm{Mg}^{2+}$ complexes of $\mathrm{pUpU}^{3-}$ and $\mathrm{pUp}(\mathrm{S}) \mathrm{U}^{3-} \cdot{ }^{73,74}$ In addition, the data points of the corresponding M(UMPS) complexes are given for comparison. ${ }^{68,69}$

insert Figure 4 close to here

insert Figure 5 close to here 
From Figure 5 it is seen that $\mathrm{Mg}^{2+}$ shows a small stability enhancement with both dinucleotides. This same stability enhancement is also found ${ }^{13,73,74}$ for the $\mathrm{Mn}(\mathrm{pUpU})^{-}$and $\mathrm{Cd}(\mathrm{pUpU})^{-}$complexes (not shown in Fig. 5). In fact, this stability enhancement corresponds to the charge effect that the negatively charged diester bridge exercises on $\mathrm{M}^{2+}$ coordinated at the terminal phosphate group. This charge effect, which amounts on average to $0.24 \pm 0.04 \log$ unit, ${ }^{13,73,74}$ needs to be deducted from the total observed stability enhancements (Table 3) to reflect the parts of the stability enhancements which are due to macrochelate formation of the metal ion bound at the terminal phosphate group with the (thio)phosphate diester bridge.

insert Table 3 close to here

The quantitative evaluation of the data seen in Figure 5 leads to the results summarized in Table 3. The amazing observation is that no macrochelate formation occurs with $\mathrm{Mg}^{2+}$ or $\mathrm{Mn}^{2+}$ and both dinucleotides, and also not with $\mathrm{Cd}(\mathrm{pUpU})^{-}$, whereas $\mathrm{Pb}^{2+}$ forms the ten-membered chelate with a formation degree of approximately $93( \pm 4) \%$ in the $\mathrm{Pb}(\mathrm{pUpU})^{-}$complex (upper part of Table 3). The corresponding formation degree for $\mathrm{Zn}(\mathrm{pUpU})^{-}$is with about $26( \pm 14) \%$ much smaller, but still real.

If one compares the results regarding the formation degrees of the $M(p U p(s) U)^{-}$complexes with those of the normal phosphate diester bridge, $\mathrm{M}(\mathrm{pUpU})^{-}$, in the two parts of Table 3, one makes several interesting observations: The whole stability enhancement observed for the $\mathrm{Cd}\left(\mathrm{pUp}_{(\mathrm{s})} \mathrm{U}\right)^{-}$complex must be attributed to a $\mathrm{Cd}^{2+}$-thio interaction because for $\mathrm{Cd}(\mathrm{pUpU})^{-}$no stability enhancement is observed. This contrasts with the $\mathrm{Zn}^{2+}$ systems, where from the approximately $26 \%$ of closed species occurring in $\mathrm{Zn}(\mathrm{pUpU})^{-}$, an increase to about $67 \%$ in total in $\mathrm{Zn}\left(\mathrm{pUp}_{(\mathrm{s})} \mathrm{U}\right)^{-}$has taken place. Hence, two forms of chelated species must exist here and consequently, Equilibrium Scheme (7) must operate:

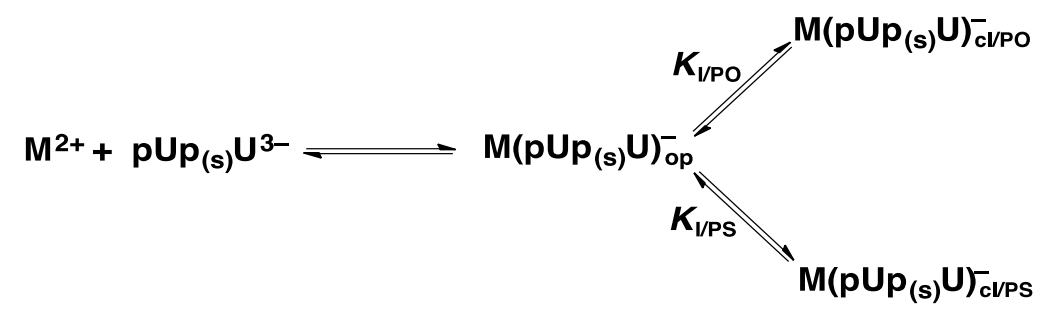

Overall one has thus to conclude that for $\mathrm{Cd}^{2+}$ only the lower pathway operates whereas for $\mathrm{Zn}^{2+}$ 
both species occur.

Most unexpected and surprising are the results with $\mathrm{Pb}^{2+}$, where the formation degree of the macrochelate of about $93( \pm 4) \%$ in $\mathrm{Pb}(\mathrm{pUpU})^{-}$is reduced to about $45( \pm 18) \%$ in $\mathrm{Pb}(\mathrm{pUp}(\mathrm{s}) \mathrm{U})^{-}$. Consequently, there is no indication for a $\mathrm{Pb}^{2+}$-thio interaction. Indeed, the reduction of the formation degree from about $90 \%$ in the phosphate diester bridge to about $45 \%$ in the thio derivative corresponds to a factor of one half and this is statistically expected if from two terminal $\mathrm{O}$ atoms in the phosphate diester bridge only one $\mathrm{O}$ atom remains in the thiophosphate diester bridge.

From the studied metal ion systems only for the $\mathrm{Zn}^{2+}$ one Equilibrium Scheme (7) is of relevance. The quantitative evaluation reveals ${ }^{74}$ that from the in total $67( \pm 8) \%$ of macrochelate present in $\mathrm{Zn}\left(\mathrm{pUp}_{(\mathrm{s})} \mathrm{U}\right)^{-}$about $12 \%$ form the $\mathrm{Zn}\left(\mathrm{pUp}_{(\mathrm{s})} \mathrm{U}\right)_{\mathrm{c} / \mathrm{Po}}^{-}$isomer and about $55 \%$ the $\mathrm{Zn}\left(\mathrm{pUp}_{(\mathrm{S})} \mathrm{U}\right)_{\mathrm{c}}^{-} / \mathrm{ps}$ one. The remaining $33( \pm 8) \%$ are due to the open isomer $\mathrm{Zn}\left(\mathrm{pUp}_{(\mathrm{s})} \mathrm{U}_{\mathbf{o p}}^{-}\right.$, in which $\mathrm{Zn}^{2+}$ is only coordinated to the terminal phosphate group (see Fig. 4). This adaptability of $\mathrm{Zn}^{2+}$ to different coordination environments ${ }^{75}$ is possibly the reason for its immense role in biosystems, ${ }^{76}$ and which contrasts with the too rigid coordination properties of the toxic $\mathrm{Cd}^{2+}$ (see Ref. 37) and $\mathrm{Pb}^{2+}$ ions. ${ }^{6}$

\section{Conclusions including the role of the lead(II) lone pair}

The most fascinating observation is that lead(II) forms very stable complexes with MeOPS and UMPS (Fig. 2) and that the PS $\cdot \mathrm{Pb}$ isomer occurs with more than $99 \%$, that is, $\mathrm{Pb}^{2+}$ behaves very thiophilic! This contrasts with the properties of $\mathrm{Pb}^{2+}$ towards the thiophosphate diester bridge in $\mathrm{pUp}_{(\mathrm{S})} \mathrm{U}^{3-}$ (Fig. 4) where $\mathrm{Pb}^{2+}$ shows no thiophilicity at all. $\mathrm{Pb}^{2+}$ coordinates here to the remaining $\mathrm{O}$ donor of the thiophosphate diester bridge in $\mathrm{pUp}_{(\mathrm{S})} \mathrm{U}^{3-}$.

It is not surprising that $\mathrm{Pb}^{2+}$ is regularly used as a hydrolytic metal ion ${ }^{77}$ for RNA, like in the in vitro selected leadzyme ${ }^{78,79}$ it is also a tool to detect metal ion binding sites, where $\mathrm{O}$ coordination is presumably important. ${ }^{77,80,81}$ To conclude, $\mathrm{Pb}^{2+}$-dependent ribozymes ${ }^{47,81-83}$ and DNAzymes ${ }^{47,81,84,85}$ are well known and render $\mathrm{Pb}^{2+}$ a widely used experimental tool in RNA biochemistry.

The reason for the unexpected property indicated above, relating to different $\mathrm{S}$ sites, is most 
likely the $6 \mathrm{~s}^{2}$ lone pair ${ }^{13,86,87}$ of $\mathrm{Pb}^{2+}$ which may give rise to a hemidirected structure as observed, e.g., for the complex $\mathrm{Pb}_{2}(\mathrm{~L})_{2}$, where $\mathrm{L}$ is the dianion of bis-salicyloylhydrazone and where $\mathrm{Pb}(\mathrm{II})$ is coordinated by two $\mathrm{N}$ and two negatively charged $\mathrm{O}$ sites, ${ }^{88}$ with the result that the vacant part (cf. also Ref. 86) of the coordination sphere of $\mathrm{Pb}^{2+}$ is occupied by the lone pair. ${ }^{88}$ Clearly, the stereochemically active $6 s^{2}$ lone pair cannot remain in a s-orbital if it is to produce an asymmetric coordination sphere. ${ }^{89}$ Depending on whether the $6 \mathrm{~s}^{2}$ lone pair causes a spherical or a non-spherical charge distribution around $\mathrm{Pb}(\mathrm{II})$, the geometry of the complexes is symmetric or distorted. ${ }^{87}$ Shimoni-Livny, Glusker, and Bock, ${ }^{90}$ among others, distinguish therefore holodirected (symmetric, with a spherical $6 s^{2}$ lone pair) and hemidirected (distorted, with a nonspherical $6 \mathrm{~s}^{2}$ lone pair) coordination spheres. ${ }^{87,90}$ Sulfur donor atoms, for example, are expected to have minimal orbital interaction with the $\mathrm{Pb}(\mathrm{II})$ 6s-orbital, thus leading to holodirected structures. ${ }^{89}$ On the other hand, hemidirected structures are favored in complexes formed by electronegative donor atoms, ${ }^{87}$ like O sites. Overall, $\mathrm{Pb}(\mathrm{II})$ acts generally as a Lewis acid. ${ }^{89}$ However, very recently evidence was presented that $\mathrm{Pb}(\mathrm{II})$ can also act as a weak base by forming a hydrogen bond. ${ }^{89}$ This is indirect evidence for the existence of a $\mathrm{Pb}(\mathrm{II})$ lone pair, though the bonding capacity of which is limited. ${ }^{89}$

As indicated above, due to the coordination of $\mathrm{Pb}^{2+}$ to the electronegative oxygen atoms of the terminal phosphate group in the dinucleotides a hemidirected coordination sphere is expected to evolve. This resulting irregularity distinguishes $\mathrm{Pb}^{2+}$ strongly from $\mathrm{Zn}^{2+}$ and from $\mathrm{Cd}^{2+}$ as well, but it leads to a coordination sphere of $\mathrm{Pb}^{2+}$ which is similar to the "square-planar" one of $\mathrm{Cu}^{2+}$ and this is probably the reason why the affinity towards O-donor sites of these two metal ions is so similar (Fig. 1; Section 2).

To conclude, $\mathrm{Pb}^{2+}$ is kind of a chameleon-like metal ion. Its binding properties depend on the first coordinating ligand; this means, there can be a directing effect of the first ligand bound. Therefore, the coordinatively unsaturated $\mathrm{Pb}\left(\mathrm{R}-\mathrm{PO}_{3}\right)$ complex, resulting from the coordination of the terminal phosphate group of $\mathrm{pUp}_{(\mathrm{s})} \mathrm{U}^{3-}$, behaves towards thio sites (Section 4) very different compared to $\mathrm{Pb}_{\text {aq }}^{2+}$ (Section 3): $\mathrm{Pb}\left(\mathrm{R}-\mathrm{PO}_{3}\right.$ ) (hemidirected) prefers additional $\mathrm{O}$ sites and $\mathrm{Pb}_{\mathbf{a q}}^{2+}$ (holodirected) S sites. 


\section{A caveat}

The preceding conclusions regarding the affinity of $\mathrm{Pb}^{2+}$ towards a thiophosphate diester bridge are certainly correct for a situation where $\mathrm{Pb}^{2+}$ is coordinated to a phosphate group or to another O-donor site that activates the $6 s^{2}$ lone pair (Section 5). However, how is the situation if "free" $\mathrm{Pb}_{\mathbf{a q}}^{2+}$ and its affinity towards a thiophosphate diester linkage is considered?

To facilitate matters we will first consider a common phosphate diester unit. Based on the $\mathrm{Pb}^{2+}$-AMP system the affinity of $\mathrm{Pb}^{2+}$ towards a monoprotonated phosphate monoester, $\mathrm{ROP}(\mathrm{O})_{2} \mathrm{OH}$, was estimated as $\log K_{\mathbf{P b}\left(\mathrm{ROP}(\mathrm{O})_{2} \mathrm{OH}\right)}^{\mathrm{Pb}}=0.7 \pm 0.4 .{ }^{91}$ If one concentrates now on the situation in a single-stranded nucleic acid, one has to consider the metal ion affinity of the four nucleobase residues versus the affinity of the phosphate diester bridge. ${ }^{31}$ However, compared to the four nucleobases, adenine, guanine, cytosine, and uracil (thymine), assuming they occur in a 1:1:1:1 ratio, the diester bridge occurs in a fourfold excess to each of them and therefore the mentioned $0.7 \pm 0.4 \log$ unit needs to be corrected by the statistical factor of 4 (0.6 log unit) giving then the micro stability constant $\log k_{\mathbf{P b}\left(\mathbf{R}^{\prime} \mathbf{O P}(\mathbf{O})_{2} \mathbf{O R}\right)}^{\mathbf{P b}}=1.3 \pm 0.4 .{ }^{31}$ If one then considers the metal ion affinities of the nucleobases as determined via their corresponding nucleosides, towards formation of the $\mathrm{Pb} \cdot \mathrm{NMP} \cdot \mathrm{H}^{+}$species, one obtains the following affinity order (the micro stability constants are given in parentheses): ${ }^{31}$ guanine-N7(O6) $(1.76 \pm 0.23) \geq$ cytosine-N3(O2) $(1.65 \pm 0.17) \geq \mathrm{R}^{\prime} \mathrm{OP}(\mathrm{O}){ }_{2}{ }_{2} \mathrm{OR}(1.3 \pm 0.4) \geq$ adenine $(0.90 \pm 0.35)>$ uracil $\simeq$ thymine

With $\mathrm{AMPS}^{2-}$ (see Fig. 2) the following isomeric monoprotonated $\mathrm{Pb}^{2+}$ complexes can be formed: One, where $\mathrm{Pb}^{2+}$ is at the adenine residue and the proton at the thiophosphate group, $\mathrm{Pb} \cdot \mathrm{AMPS} \cdot \mathrm{H}^{+}$; a further one where $\mathrm{H}^{+}$and $\mathrm{Pb}^{2+}$ have changed the place, $\mathrm{H} \cdot \mathrm{AMPS} \cdot \mathrm{Pb}^{+}$; and a third one where both, $\mathrm{Pb}^{2+}$ and $\mathrm{H}^{+}$, are located at the thiophosphate group of AMPS ${ }^{2-}$, AMPS $\cdot \mathrm{Pb} \cdot \mathrm{H}^{+}$. Evidently this latter species mimics to some extent a thiophosphate diester unit and the corresponding micro stability constant was estimated as $\log k_{\mathrm{AMPS} \cdot \mathrm{Pb} \cdot \mathrm{H}}^{\mathrm{Pb}}=2.6 \pm 0.4{ }^{68}$ This stability constant is much lower than the one for the $\mathrm{Pb}$ (AMPS) complex in which no macrochelation with N7 occurs; ${ }^{68}$ this constant equals $\log K_{\mathbf{P b} \text { (AMPS) }}^{\mathbf{P b}}=4.77 \pm 0.10,{ }^{68}$ a value practically identical with the one measured for $\mathrm{Pb}(\mathrm{MeOPS})$ (see Table 1 and Fig. 3). However, this value of $2.6 \pm 0.4 \log$ units is still much higher than all the affinity constants given above for 
the nucleobase residues in a single-stranded nucleic acid. In other words, if a thiophosphate diester unit is exposed to a "free" $\mathrm{Pb}_{\mathbf{a q}}^{2+}$ ion, a $\mathrm{Pb}^{2+}-\mathrm{S}$ interaction is expected to occur. These reasonings confirm the conclusion reached already above that $\mathrm{Pb}^{2+}$ is a chameleon-like metal ion.

\section{Conflicts of interest}

There are no conflicts of interest to declare.

\section{Acknowledgments}

The support of our work (H.S.) by the Department of Chemistry of the University of Basel, Switzerland, is gratefully acknowledged, as is the support for R.K.O.S. by the Swiss National Science Foundation and the University of Zürich.

\section{Notes and references}

‡ Abbreviations: $\mathrm{AMP}^{2-}$, adenosine 5'-monophosphate; $\mathrm{CTP}^{4-}$, cytidine 5'-triphosphate; $K_{\mathrm{I}}=$ intramolecular dimensionless equilibrium constant; $\log K$, $\log$ of a stability constant of a complex; $\mathrm{M}^{2+}$, divalent metal ion; $\mathrm{p} K$, negative logarithm of an acidity constant of a ligand or a complex; PO•M, O-coordinated isomeric complex; PS•M, S-coordinated isomeric complex. Further abbreviations are defined in the legends for Figures 1 through 4 .

1 R. A. Goyer, in Handbook on Toxicity of Inorganic Compounds; Eds H. G. Seiler, H. Sigel and A. Sigel; Dekker, New York, 1988, pp. 359-382.

2 R. B. Martin, Met. Ions Biol. Syst., 1986, 20, 21-65; see also Chapter 2 in Ref. 3.

3 Concepts on Metal Ion Toxicity (Vol. 20 of Metal Ions in Biological Systems), Eds H. Sigel and A. Sigel; Dekker, New York, 1986, pp. 1-386.

4 J. Molin Christensen and J. Kristiansen, in Handbook on Metals, in Clinical and Analytical Chemistry; Eds H. G. Seiler, A. Sigel and H. Sigel; Dekker, New York, 1994, pp. 425-440. 
5 S. Caito, A. C. B. Almeida Lopes, M. M. B. Paoliello and M. Aschner, Met. Ions Life Sci., 2017, 17, pp. 501-534; see also Chapter 16 in Ref. 6.

6 Lead: Its Effects on Environment and Health (Vol. 17 of Metal Ions in Life Sciences), Eds A. Sigel, H. Sigel and R. K. O. Sigel; De Gruyter, Berlin, 2017, pp. 1-555.

7 J.-H. Yoon, Y.-S. Ahn, J. Affective Disord., 2016, 190, 41-46.

8 J. Arora, A. K. Choudhary, S. S. Kishanrao, J. Gumashta, Int. J. Pharma Bio Sciences, 2015, 6, 600-605.

9 F. M. Johnson, Mutation Res., 1998, 410, 123-140.

10 L. Zhen, Y. Yu, L. Xiaohong, W. Aimin, M. Mingdao, L. Nana, D. Ying, J. Xi, L. Shengli, L. Yuan, C. Xinlin, W. Fudi and Z. Jun, Reproductive Toxicol., 2015, 51, 1-6.

11 L. Xu, J. Ge, X. Huo, Y. Zhang, A. T. Y. Lau and X. Xu, Sci. Total Environment, 2016, 550, 1163-1170.

12 R. B. Martin, in Handbook on Toxicity of Inorganic Compounds; Eds H. G. Seiler, H. Sigel and A. Sigel; Dekker, New York, 1988, pp. 9-25.

13 A. Sigel, B. P. Operschall and H. Sigel, Met. Ions Life Sci., 2017, 17, 319-402, see also Chapter 11 in Ref. 6.

14 P. B. Hammond and E. C. Foulkes, Met. Ions Biol. Syst., 1986, 20, 157-200; see also Chapter 6 in Ref. 3.

15 H. R. Pohl, S. Z. Ingber and H. G. Abadin, Met. Ions Life Sci., 2017, 17, 435-470; see also Chapter 13 in Ref. 6.

16 M. Filella and J. Bonet, Met. Ions Life Sci., 2017, 17, 471-490; see also Chapter 14 in Ref. 6.

17 W. Mao, J. Zheng, Y. Zhang, A. S. R. Chesman, Q. Ou, J. Hicks, F. Li, Z. Wang, B. Graystone, T. D. M. Bell, M. U. Rothmann, N. W. Duffy, L. Spiccia, Y.-B. Cheng, Q. Bao and U. Bach, Angew. Chem. Int. Ed., 2017, 56, 12486-12491.

18 L. Yuan, W. Zhi, Y. Liu, S. Karyala, P. J. Vikesland, X. Chen and H. Zhang, Environ. Sci. Technol., 2015, 49, 824-830.

19 M. Alushllari, J. Internat. Environmental Application \& Science, 2015, 10, 108-112.

20 W. Maret, Met. Ions Life Sci., 2017, 17, 1-20; see also Chapter 1 in Ref. 6. 
21 J. T. Cullen and J. McAlister, Met. Ions Life Sci., 2017, 17, 21-48; see also Chapter 2 in Ref. 6.

22 O. F. Sanchez, J. Lee, N. Y. K. Hing, S.-E. Kim, J. L. Freeman and C. Yuan, Metallomics, 2017, 9, 149-160.

23 T. J. Stewart, Met. Ions Life Sci., 2017, 17, 79-97; see also Chapter 5 in Ref. 6.

24 K. Klotz and T. Göen, Met. Ions Life Sci., 2017, 17, 99-121; see also Chapter 6 in Ref. 6.

25 H. Küpper, Met. Ions Life Sci., 2017, 17, 491-500; see also Chapter 15 in Ref. 6.

26 K. Deibler and P. Basu, Eur. J. Inorg. Chem., 2013, 1086-1096.

27 A. Tian, Y. Liu and J. Gao, Talanta, 2017, 171, 185-189.

28 X. Wang, C. Yang, M. Yan and J. Yu, New J. Chem., 2017, 41, 7052-7060.

29 H. Liao, G. Liu, Y. Liu, R. Li, W. Fu and L. Hu, Chem. Commun., 2017, 53, 10160-10163.

30 P. C. Hauser, Met. Ions Life Sci., 2017, 17, 49-59; see also Chapter 3 in Ref. 6.

31 H. Sigel, C. P. Da Costa and R. B. Martin, Coord. Chem. Rev., 2001, 219-221, 435- 461.

32 H. M. Irving and R. J. P. Williams, Nature, 1948, 162, 746-747.

33 H. M. Irving and R. J. P. Williams, J. Chem. Soc., 1953, 3192-3210.

34 H. Sigel and R. Griesser, Chem. Soc. Rev., 2005, 34, 875-900.

35 F. M. Al-Sogair, B. P. Operschall, A. Sigel, H. Sigel, J. Schnabl and R. K. O. Sigel, Chem. Rev., 2011, 111, 4964-5003.

36 R. K. O. Sigel, M. Skilandat, A. Sigel, B. P. Operschall and H. Sigel, Met. Ions Life Sci., 2013, 11, 191-274; see also Chapter 8 of Ref. 37.

37 Cadmium: From Toxicity to Essentiality (Vol. 11 of Metal Ions in Life Sciences), Eds A. Sigel, H. Sigel and R. K. O. Sigel; Springer, Dordrecht, 2013; pp. 1-560.

38 S. A. A. Sajadi, B. Song, F. Gregáň and H. Sigel, Inorg. Chem., 1999, 38, 439-448.

39 B. Knobloch and H. Sigel, J. Biol. Inorg. Chem., 2004, 9, 365-373.

40 NIST Critically Selected Stability Constants of Metal Complexes, Reference Database 46, Version 6; data collected and selected by R. M. Smith and A. E. Martell, U. S. Department of Commerce, National Institute of Standards and Technology, Gaithersburg, MD, USA, 2001.

41 R. B. Martin, in Encyclopedia of Inorganic Chemistry, Vol. 4; Ed. R. B. King; Wiley, 
Chichester, U.K., 1994, pp. 2185-2196.

42 R. B. Martin, in Encyclopedia of Molecular Biology and Molecular Medicine, Vol. 1; Ed. R. A. Meyers; VCH, Weinheim, Germany, 1996, pp. 125-134.

43 R. K. O. Sigel and H. Sigel, Acc. Chem. Res., 2010, 43, 974-984.

44 A. M. Pyle, Met. Ions Biol. Syst., 1996, 32, 479-520.

45 J. E. Huheey, Inorganic Chemistry; 3rd Edit.; Harper and Row, New York, 1983, pp. 1-936.

46 L. Claus, S. Vortler and F. Eckstein, Methods Enzymol., 2000, 317, 74-91.

47 R. K. O. Sigel, Eur. J. Inorg. Chem., 2005, 2281-2292.

48 X. Yang, N. D. Abeydeera, F.-W. Liu and M. Egli, Chem. Commun., 2017, 53, 1050810511.

49 K. L. Warfield, R. G. Pachal, M. J. Aman and S. Bavari, Curr. Opin. Mol. Ther., 2006, 8, 93-103.

50 F. Eckstein, Nucleic Acid Ther., 2014, 24, 374-387.

51 S. D. Laufer, A. Detzer, G. Sczakiel and T. Restle, in RNA Technologies and Their Applications; Eds V. A. Erdmann and J. Barciszewski; Springer, Berlin, 2010, pp. 29-59.

52 H. Jahns, M. Roos, J. Imig, F. Baumann, Y. Wang, R. Gilmour and J. Hall, Nature Commun., 2015, 6, Article No. 6317; DOI 10.1038/ncomms7317.

53 P. Guga and M. Koziołkiewicz, Chem. Biodiv., 2011, 8, 1642-1681.

54 M. C. Erat, E. Besic, M. Oberhuber, S. Johannsen and R. K. O. Sigel, J. Biol. Inorg. Chem., 2018, 23, 167-177.

55 A. Sigel, B. P. Operschall, A. Matera-Witkiewicz, J. Świątek-Kozłowska and H. Sigel, Coord. Chem. Rev., 2016, 327-328, 200-220.

56 D. Bouvier, N. Labessan, M. Clémancey, J.-M. Latour, J.-L. Ravanat, M. Fontecave, and M. Atta, Nucleic Acids Res., 2014, 42, 7960-7970.

57 I. Deb, J. Sarzynska, L. Nilsson and A. Lahiri, J. Chem. Inf. Model., 2014, 54, 1129-1142.

58 K. Aoki, Met. Ions Biol. Syst., 1996, 32, 91-134.

59 H. Sigel and B. Song, Met. Ions Biol. Syst., 1996, 32, 135-205.

60 R. B. Martin and Y. H. Mariam, Met. Ions Biol. Syst., 1979, 8, 57-124.

61 D. B. Davies, P. Rajani and H. Sadikot, J. Chem. Soc., Perkin Trans. 2, 1985, 279-285. 
62 R. Tribolet and H. Sigel, Eur. J. Biochem., 1987, 163, 353-363.

63 S. S. Massoud and H. Sigel, Inorg. Chem., 1988, 27, 1447-1453.

64 H. Sigel, D. Chen, N. A. Corfù, F. Gregán̆, A. Holý and M. Strašák, Helv. Chim. Acta, 1992, 75, 2634-2656.

65 B. Song, R. K. O. Sigel and H. Sigel, Chem. Eur. J., 1997, 3, 29-33.

66 P. A. Frey and R. D. Sammons, Science, 1985, 228, 541-545.

67 P. A. Frey, Adv. Enzymol. Related Areas Mol. Biol., 1989, 62, 119-201.

68 C. P. Da Costa, D. Krajewska, A. Okruszek, W. J. Stec and H. Sigel, J. Biol. Inorg. Chem., 2002, 7, 405-415.

69 C. P. Da Costa, A. Okruszek and H. Sigel, ChemBioChem, 2003, 4, 593-602.

70 H. Sigel, S. S. Massoud and N. A. Corfù, J. Am. Chem. Soc., 1994, 116, 2958-2971.

71 H. Sigel and L. E. Kapinos, Coord. Chem. Rev., 2000, 200-202, 563-594.

72 R. K. O. Sigel, B. Song and H. Sigel, J. Am. Chem. Soc., 1997, 119, 744-755.

73 B. Knobloch, D. Suliga, A. Okruszek and R. K. O. Sigel, Chem. Eur. J., 2005, 11, 41634170.

74 B. Knobloch, B. Nawrot, A. Okruszek and R. K. O. Sigel, Chem. Eur. J., 2008, 14, 31003109.

75 H. Sigel and R. B. Martin, Chem. Soc. Rev., 1994, 23, 83-91.

76 Handbook on Metalloproteins, Eds I. Bertini, A. Sigel and H. Sigel, Dekker, New York, 2001, pp. 1-1182.

77 R. K. O. Sigel, A. Vaidya and A. M. Pyle, Nature Struct. Biol., 2000, 7, 1111-1116.

78 T. Pan and O. C. Uhlenbeck, Biochemistry, 1992, 31, 3887-3895.

79 T. Pan and O. C. Uhlenbeck, Nature, 1992, 358, 560-563.

80 M. C. Erat and R. K. O. Sigel, Met. Ions Life Sci., 2011, 9, 37-100.

81 J. Palou-Mir, M. Barceló-Oliver and R. K. O. Sigel, Met. Ions Life Sci., 2017, 17, 403-434; see also Chapter 12 in Ref. 6.

82 M. Pechlaner and R. K. O. Sigel, Met. Ions Life Sci., 2012, 10, 1-42; see also Chapter 1 in Ref. 83.

83 Interplay between Metal Ions and Nucleic Acids (Vol. 10 of Metal Ions in Life Sciences), 
Eds A. Sigel, H. Sigel and R. K. O. Sigel; Springer, Dordrecht, 2012, pp. 1-353.

84 A. K. Brown, J. Li, C. M. B. Pavot and Y. Lu, Biochemistry, 2003, 42, 7152-7161.

85 T. Lan and Y. Lu, Met. Ions Life Sci., 2012, 10, 217-248; see also Chapter 8 in Ref. 83.

86 K. Aoki, K. Murayama and N.-H. Hu, Met. Ions Life Sci., 2017, 17, 123-199; see also Chapter 7 in ref. 6.

87 E. Farkas and P. Buglyó, Met. Ions Life Sci., 2017, 17, 201-240; see also Chapter 8 in Ref. 6.

88 M. J. Romero, R. Carballido, L. Rodriguez-Silva, M. Maneiro, G. Zaragoza, A. M. González-Noya and R. Pedrido, Dalton Trans., 2016, 45, 16162-16165.

89 J. Harrowfield and P. Thuéry, Dalton Trans., 2017, 46, 11533-11536.

90 L. Shimoni-Livny, J. P. Glusker and C. W. Bock, Inorg. Chem., 1998, 37, 1853-1867.

91 C. P. Da Costa and H. Sigel, Inorg. Chem., 2000, 39, 5985-5993. 
Table 1 Comparison of the acid-base and metal ion-binding properties of phosphorothioates with those of phosphate groups $\left(25^{\circ} \mathrm{C} ; I=0.1 \mathrm{M}, \mathrm{NaNO}_{3}\right)^{\mathrm{a}, \mathrm{b}}$

\begin{tabular}{lcc}
\hline $\mathrm{R}-P O_{3}^{2-}$ & $\left.\mathrm{p} K_{\mathrm{H}(\mathrm{R}-\mathrm{PO}}^{\mathrm{H}}\right)$ & $\log \mathbf{p} K_{\mathbf{P b}\left(\mathbf{R}-\mathbf{P O} \mathbf{O}_{3}\right)}^{\mathbf{P b}}$ \\
\hline $\mathrm{CH}_{3} \mathrm{OP}(\mathrm{S})(\mathrm{O})_{2}^{2-}\left(\mathrm{MeOPS}^{2-}\right)$ & $4.96 \pm 0.02$ & $4.78 \pm 0.06$ \\
$\mathrm{UMPS}^{2-}$ & $4.78 \pm 0.02$ & $4.63 \pm 0.03$ \\
$\mathrm{CH}_{3} \mathrm{OPO}_{3}^{2-}\left(\mathrm{MeOP}^{2-}\right)$ & $6.36 \pm 0.01$ & $2.98 \pm 0.11$ \\
$\mathrm{UMP}^{2-}$ & $6.15 \pm 0.01$ & $2.80 \pm 0.04$ \\
\hline
\end{tabular}

a The given constants are defined according to Eqs (1) and (2). The listed data are collected from tables 1 and 2 in Ref. 68 (see also Ref. 31).

b The error limits are three times the standard error of the mean value $(3 \sigma)$ or the sum of the probable systematic errors, whichever is larger. The error of any of the derived data (e.g., in Table 2) were calculated according to the error propagation after Gauss. 
Table 2 Stability enhancements [Eq. (3)] for M(PS) complexes formed by $\mathrm{Ca}^{2+}, \mathrm{Zn}^{2+}, \mathrm{Cd}^{2+}$ or $\mathrm{Pb}^{2+}$ and methyl thiophosphate (MeOPS ${ }^{2-}$ ), uridine 5'-O-thiomonophosphate (UMPS ${ }^{2-}$ ) or adenosine 5'-O-thiomonophosphate $\left(\mathrm{AMPS}^{2-}\right.$ ) (aq. sol.; $25^{\circ} \mathrm{C} ; \mathrm{I}=0.1 \mathrm{M}, \mathrm{NaNO}_{3}$ )

\begin{tabular}{|c|c|c|c|c|}
\hline $\mathrm{M}(\mathrm{PS})$ & $\log \Delta_{\mathrm{M} / \mathrm{PS}}{ }^{\mathrm{a}}$ & $\log \Delta_{\mathrm{M} / \mathrm{PS} / \mathrm{av}}^{\mathrm{b}}$ & $K_{\mathrm{I}}^{\mathrm{c}}$ & $\% \mathrm{PS} \cdot \mathrm{M}^{\mathrm{C}}$ \\
\hline $\mathrm{Ca}(\mathrm{MeOPS})$ & $-0.04 \pm 0.08$ & \multirow{3}{*}{$-0.04 \pm 0.04$} & \multirow{3}{*}{$\sim 0$} & \multirow{3}{*}{$\sim 0$} \\
\hline Ca(UMPS) & $-0.07 \pm 0.11$ & & & \\
\hline Ca(AMPS) & $-0.04 \pm 0.10$ & & & \\
\hline Zn(MeOPS) & $0.65 \pm 0.08$ & \multirow{3}{*}{$0.63 \pm 0.05$} & \multirow{3}{*}{$3.3 \pm 0.05$} & \multirow{3}{*}{$76.6 \pm 2.7$} \\
\hline Zn(UMPS) & $0.58 \pm 0.08$ & & & \\
\hline Zn(AMPS) & $0.66 \pm 0.21$ & & & \\
\hline Cd(MeOPS) & $2.47 \pm 0.08$ & \multirow{3}{*}{$2.41 \pm 0.06$} & \multirow{3}{*}{$256 \pm 36$} & \multirow{3}{*}{$99.6 \pm 0.1$} \\
\hline Cd(UMPS) & $2.40 \pm 0.09$ & & & \\
\hline Cd(AMPS) & $2.37 \pm 0.15$ & & & \\
\hline $\mathrm{Pb}(\mathrm{MeOPS})$ & $2.46 \pm 0.10$ & \multirow{3}{*}{$2.48 \pm 0.10$} & \multirow{3}{*}{$301 \pm 70$} & \multirow{3}{*}{$99.7 \pm 0.1$} \\
\hline Pb(UMPS) & $2.40 \pm 0.09$ & & & \\
\hline Pb(AMPS) & $2.57 \pm 0.17$ & & & \\
\hline
\end{tabular}

${ }^{a}$ For the error limits $(3 \sigma)$ see footnote "b" of Table 1. The values for the MeOPS and UMPS systems are from Ref. 69 and those for the AMPS systems are from Refs 68 and 72. The stability enhancement due to macrochelate formation with N7 in the M(AMPS) complexes was deducted $^{72}$ to obtain only the effect of the $\mathrm{M}^{2+}$-thio coordination (see also table 9 in Ref. 13). The acidity constants are for $\mathrm{H}(\mathrm{MeOPS})^{-} \mathrm{p} K_{\mathrm{H}(\mathrm{MeOPS})}^{\mathrm{H}}=4.96 \pm 0.02,{ }^{69}$ for $\mathrm{H}(\mathrm{UMPS})^{-} \mathrm{p} K_{\mathrm{H}(\mathrm{UMPS})}^{\mathrm{H}}=$ $4.78 \pm 0.02$ and $\mathrm{p} K_{\mathrm{UMPS}}^{\mathrm{H}}=9.47 \pm 0.02,{ }^{69}$ and for $\mathrm{H}_{2}(\mathrm{AMPS})^{ \pm} \mathrm{p}_{\mathrm{H}_{2} \text { (AMP) }}^{\mathrm{H}}=3.72 \pm 0.03$ and $\mathrm{p} K_{\mathrm{H}(\mathrm{AMPS})}^{\mathrm{H}}=4.83 \pm 0.02 ; 65,72$ the micro acidity constants for $\mathrm{H}_{2}(\mathrm{AMPS})^{ \pm}$are $\mathrm{p} k_{\mathrm{H} \cdot \mathrm{AMPS} \cdot \mathrm{H}}^{\text {AMPS }}=3.84$ $\pm 0.02\left[(\mathrm{~N} 1) \mathrm{H}^{+}\right.$deprotonation] and $p k_{\text {AMPS } \cdot \mathrm{H}}^{\text {AMPS }}=4.71 \pm 0.04$ (deprotonation of the thiophosphate group).$^{65}$

b Arithmetic mean with $2 \sigma$ as error limit.

c Calculated according to Eqs (4) to (6); for details see, e.g., Refs 13, 69, and 72. 
Table 3 Comparison of the enhanced complex stabilities, $\log \Delta_{\mathrm{M} / \mathrm{pUpU}}$ or $\log \Delta_{\mathrm{M} / \mathrm{pUp}(\mathrm{S})}^{\mathrm{U}}$ [analogous to Eq. (3)], of several $\mathrm{M}(\mathrm{pUpU})^{-}$or $\mathrm{M}(\mathrm{pUp}(\mathrm{s}) \mathrm{U})^{-}$complexes and extent of the (total) intramolecular macrochelate formation involving non-bridging oxygen or sulfur atoms of the phosphodiester linkage (aq. sol.; $\left.25^{\circ} \mathrm{C}, I=0.1 \mathrm{M}, \mathrm{NaNO}_{3}\right)^{\mathrm{a}}$

\begin{tabular}{lcclc}
\hline $\mathrm{M}^{2+}$ & $\log \Delta_{\mathrm{M} / \mathrm{pUpU}}{ }^{\mathrm{b}}$ & $\log \Lambda_{\mathrm{M} / \mathrm{pUpU}^{\mathrm{b}}}^{*}$ & $K_{\mathrm{I}}^{\mathrm{c}}$ & $\% \mathrm{M}(\mathrm{pUpU})_{\mathrm{cl}}^{-\mathrm{d}}$ \\
\hline $\mathrm{Mg}^{2+}$ & $0.23 \pm 0.05^{*}$ & $-0.01 \pm 0.06$ & $\sim 0$ & $\sim 0(<11)$ \\
$\mathrm{Mn}^{2+}$ & $0.27 \pm 0.07^{*}$ & $0.03 \pm 0.08$ & $\sim 0$ & $\sim 0(<22)$ \\
$\mathrm{Zn}^{2+}$ & $0.37 \pm 0.07$ & $0.13 \pm 0.08$ & $0.35 \pm 0.25$ & $26 \pm 14$ \\
$\mathrm{Cd}^{2+}$ & $0.23 \pm 0.05^{*}$ & $-0.01 \pm 0.06$ & $\sim 0$ & $\sim 0(<11)$ \\
$\mathrm{Pb}^{2+}$ & $1.40 \pm 0.26$ & $1.16 \pm 0.26$ & $13.45 \pm 8.65$ & $93 \pm 4$ \\
\hline $\mathrm{M}^{2+}$ & $\log \Delta_{\mathrm{M} / \mathrm{pUp}(\mathrm{S})^{\mathrm{U}}}$ & $\log \Lambda_{\mathrm{M} / \mathrm{pUp}(\mathrm{s})^{\mathrm{U}}}^{\mathrm{e}}$ & $K_{\mathrm{I} / \mathrm{tot}}^{\mathrm{c}, \mathrm{f}}$ & $\% \mathrm{M}(\mathrm{pUp}(\mathrm{s}) \mathrm{U})_{\mathrm{cl} / \mathrm{tot}}^{\mathrm{d}, \mathrm{f}, \mathrm{g}}$ \\
\hline $\mathrm{Mg}^{2+}$ & $0.26 \pm 0.08^{\mathrm{h}}$ & $0.02 \pm 0.09$ & $\sim 0$ & $\sim 0(<22)$ \\
$\mathrm{Mn}^{2+}$ & $0.23 \pm 0.09^{\mathrm{h}}$ & $-0.01 \pm 0.10$ & $\sim 0$ & $\sim 0(<19)$ \\
$\mathrm{Zn}^{2+}$ & $0.72 \pm 0.09$ & $0.48 \pm 0.10$ & $2.02 \pm 0.68$ & $67 \pm 8$ \\
$\mathrm{Cd}^{2+}$ & $0.68 \pm 0.09$ & $0.44 \pm 0.10$ & $1.75 \pm 0.62$ & $64 \pm 8$ \\
$\mathrm{~Pb}^{2+}$ & $0.50 \pm 0.14$ & $0.26 \pm 0.15$ & $0.82 \pm 0.61$ & $45 \pm 18$ \\
\hline
\end{tabular}

a The data are collected for the $\mathrm{pUpU}^{3-}$ systems (upper part of this table) from Ref. 73 and for the $\mathrm{pUp}_{(\mathrm{s})} \mathrm{U}^{3-}$ systems (lower part) from Ref. 74 (see also Ref. 13). For the error limits $(3 \sigma)$ see footnote "b" of Table 1.

b Note, $\log \Delta_{\mathrm{M} / \mathrm{pUpU}}^{*}=\log \Delta_{\mathrm{M} / \mathrm{pUpU}}-\log \Delta_{\mathrm{M} / \mathrm{pUpU} / \mathrm{charge}}$. The latter value is the average of the three marked values $\left(^{*}\right)$ in column 2 , which amounts to $0.24 \pm 0.04 \log$ unit, and which represents the charge effect that the negatively charged phosphate diester bridge exercizes on $\mathrm{M}^{2+}$ coordinated at the terminal phosphate group.

c Defined in analogy to Eq. (5).

${ }^{\mathrm{d}}$ Calculated in analogy to Eq. (6).

${ }^{\text {e }}$ Here the charge effect of the phosphate diester bridge, log $\Delta_{\mathrm{M} / \mathrm{pUpU} / \mathrm{charge}}=0.24 \pm 0.04$, as defined in the upper part of this table, is taken into account, that is, $\log \Lambda_{\mathbf{M} / \mathbf{p U}(\mathbf{s}) \mathrm{U}}^{*}=\log$ $\square \Delta_{\mathrm{M} / \mathrm{pUp}(\mathrm{S}) \mathrm{U}}-\log \Delta_{\mathrm{M} / \mathrm{pUpU} / \text { charge }}$

${ }^{\mathrm{f}}$ tot = total; this means that the sum of both closed isomers of Eq. (7) is considered.

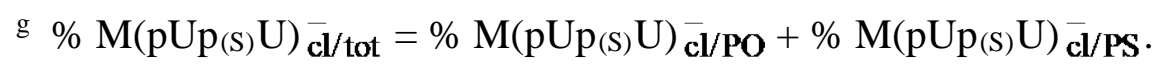

h These values for the $\mathrm{Mg}^{2+}$ and $\mathrm{Mn}^{2+} / \mathrm{pUp}_{(\mathrm{S})} \mathrm{U}^{3-}$ systems confirm the charge effect defined in the upper part of this table. ${ }^{\text {b }}$ 


\section{Legends of the Figures}

Fig. 1 Irving-Williams sequence-type plots ${ }^{32,33}$ for the $1: 1$ complexes of $\mathrm{Ca}^{2+}$ through $\mathrm{Zn}^{2+}$ plus $\mathrm{Cd}^{2+}$ and $\mathrm{Pb}^{2+}$ formed with mono- (R-MP ${ }^{2-}$ ), di- (R-DP $\left.{ }^{3-}\right)$, and triphosphate monoesters (R-TP ${ }^{4-}$ ) as well as of those for acetate $\left(\mathrm{Ac}^{-}\right)$, which is used as a simple mimic for the $(\mathrm{RO})_{2} \mathrm{PO}_{2}^{-}$unit (RP represents all four ligands). The acidity constants of the corresponding monoprotonated species are $\mathrm{p} K_{\mathrm{H}(\mathrm{R}-\mathrm{MP})}^{\mathrm{H}}=6.20,{ }^{34} \mathrm{p} K_{\mathrm{H}(\mathrm{R}-\mathrm{DP})}^{\mathrm{H}}=6.40,{ }^{34} \mathrm{p} K_{\mathrm{H}(\mathrm{R}-\mathrm{TP})}^{\mathrm{H}}=6.50,{ }^{34}$ and $\mathrm{p} K_{\mathrm{H}(\mathrm{Ac})}^{\mathrm{H}}=4.6 .{ }^{35-37}$ The plotted data of the phosphate ligands are from the compilations given in Refs 34 (table 13) and 36 (table 7); those for the corresponding $\mathrm{Cd}^{2+}$ and $\mathrm{Pb}^{2+}$ complexes are from Refs 36, 38 and 31, respectively. These values also represent the stability constants for the $\mathrm{M}^{2+}$ complexes of the pyrimidine-nucleoside 5'-mono-, di- or triphosphates [except for $\left.\mathrm{Cu}(\mathrm{CTP})^{2-}\right]^{38,39}\left(25^{\circ} \mathrm{C} ; I=0.1\right.$ $\left.\mathrm{M}, \mathrm{NaNO}_{3}\right)$. The log stability constants of the $\mathrm{M}(\mathrm{Ac})^{+}$complexes are collected from Ref. 40. -This figure and part of its legend are reproduced from our publication in Met. Ions Life Sci. 17 (2017), Chapter 11 (figure 15) ${ }^{13}$ with permission of the Copyright owner Walter de Gruyter GmbH, Berlin, Germany.

Fig. 2 Chemical structures of methyl thiophosphate $\left(\mathrm{MeOPS}^{2-}\right)$, uridine 5'-Othiomonophosphate (UMPS ${ }^{2-}$ ), and adenosine 5'-O-thiomonophosphate (AMPS ${ }^{2-}$ ). The nucleotide analogues, i.e., $\mathrm{UMPS}^{2-}$ and $\mathrm{AMPS}^{2-}$, are shown in their anti conformation. ${ }^{58-62}$

Fig. 3 Evidence for an enhanced stability of the $\mathrm{Pb}^{2+}$ (black), $\mathrm{Cd}^{2+}$ (green), and $\mathrm{Zn}^{2+}$ (red) 1:1 complexes (filled circles) of $\mathrm{UMPS}^{2-}$ and $\mathrm{MeOPS}^{2-}$, as well as evidence of a non-affected (i.e., not increased) complex stability of their $\mathrm{Ca}^{2+}$ (blue) 1:1 complexes. ${ }^{69}$ Also no increased stability is observed for the $\mathrm{Pb}^{2+}$ (black), $\mathrm{Cd}^{2+}$ (green), $\mathrm{Zn}^{2+}$ (red), and $\mathrm{Ca}^{2+}$ (blue) 1:1 complexes ${ }^{69}$ (crossed circles) of the parent ligands $\mathrm{UMP}^{2-}$ and $\mathrm{MeOP}^{2-}\left(=\right.$ methyl phosphate $=\mathrm{CH}_{3} \mathrm{OPO}_{3}^{2-}$ ) based on the straight-line relationship between $\log K_{\mathrm{M}\left(\mathrm{R}-\mathrm{PO}_{3}\right)}^{\mathrm{M}}$ [Eq. (1)] and $\mathrm{p} K_{\mathrm{H}\left(\mathrm{R}-\mathrm{PO}_{3}\right)}^{\mathrm{H}}$ [Eq. (2)] for $\mathrm{M}\left(\mathrm{R}-\mathrm{PO}_{3}\right)$ complexes of some simple phosphate monoester and phosphonate ligands (R-PO ${ }_{3}^{2-}$ ) (empty circles): 4-nitrophenyl phosphate $\left(\mathrm{NPhP}^{2-}\right)$, phenyl phosphate $\left(\mathrm{PhP}^{2-}\right)$, uridine 5'-monophosphate (UMP ${ }^{2-}$, crossed circle), D-ribose 5-monophosphate (RibMP $\left.{ }^{2-}\right)$, thymidine (= 1-(2'-deoxy- $\beta$-D-ribofuranosyl)thymine) 5'-monophosphate (dTMP $\left.{ }^{2-}\right), n$-butyl phosphate 
$\left(\mathrm{BuP}^{2-}\right)$, methanephosphonate $\left(\mathrm{MeP}^{2-}\right)$, and ethanephosphonate ( $\left.\mathrm{EtP}^{2-}\right)$ (from left to right). The least-squares straight lines are drawn through the corresponding eight data sets taken from Ref. 63 for the phosphate monoesters and from Ref. 64 for the phosphonates. The straight-line parameters for $\mathrm{Pb}^{2+}$ are listed in Ref. 68; those for the other metal ions in Refs 59, 64, 70, and 71. The points due to the equilibrium constants for the $\mathrm{M}^{2+} / \mathrm{PS}$ systems ${ }^{69}$ are based on the values listed in Table 2 and the Refs given there. The vertical dotted lines emphasize the stability differences to the reference lines; they equal $\log \Delta_{\mathrm{M} / \mathrm{PS}}$ (Table 2) as defined in Eq. (3) for the M(PS) complexes. All the plotted equilibrium constants refer to aqueous solutions at $25^{\circ} \mathrm{C}$ and $I$ $=0.1 \mathrm{M}\left(\mathrm{NaNO}_{3}\right)$.

Fig. 4 Chemical structures of the trianions of uridylyl-(5' $\left.\rightarrow 3^{\prime}\right)-\left[5^{\prime}\right]-$-uridylate $\left(\mathrm{pUpU}^{3-}\right)$ and of its thio derivative $P$-thiouridylyl-(5' $\left.\rightarrow 3^{\prime}\right)$-[5']-uridylate $\left(\mathrm{pUp}_{(\mathrm{S})} \mathrm{U}^{3-}\right)$ with the two uridine units in each dinucleotide in the predominant anti conformation. ${ }^{58-61}$ Regarding the thiophosphate diester bridge one may add (mainly based on information available for thiophosphate) that, if protonated, $\mathrm{H}^{+}$is mostly bound at the terminal $\mathrm{O}$ atom of this bridge ${ }^{65,68}$ After deprotonation the negative charge of the thiophosphate bridge is mainly located at the sulfur atom, ${ }^{65-67}$ as is depicted in the above $\mathrm{pUp}(\mathrm{s}) \mathrm{U}^{3-}$ structure.

Fig. 5 Evidence for an enhanced stability of the $\mathrm{M}(\mathrm{pUpU})^{-}$and $\mathrm{M}(\mathrm{pUp}(\mathrm{s}) \mathrm{U})^{-}$complexes of $\mathrm{Pb}^{2+}, \mathrm{Zn}^{2+}$, and $\mathrm{Mg}^{2+}$, based on $\log K_{\mathrm{M}\left(\mathrm{R}-\mathrm{PO}_{3}\right)}^{\mathrm{M}}$ versus $\mathrm{p} K_{\mathrm{H}\left(\mathrm{R}-\mathrm{PO}_{3}\right)}^{\mathrm{H}}$ straight-line plots for $\mathrm{M}(\mathrm{R}-$ $\mathrm{PO}_{3}$ ) complexes, where $\mathrm{R}-\mathrm{PO}_{3}^{2-}$ encompasses the same list of eight ligands given in the legend of Figure 3. The least-squares lines are drawn through the indicated eight data sets; ${ }^{63,64}$ the straight-line parameters for $\mathrm{Pb}^{2+}$ are listed in Ref. 68; those for the other metal ions in Refs 59, 64, 70, and 71. The data points for the $\mathrm{M}^{2+} / \mathrm{H}^{+} / \mathrm{pUpU}^{3-}$ and $\mathrm{M}^{2+} / \mathrm{H}^{+} / \mathrm{pUp}_{(\mathrm{S})} \mathrm{U}^{3-}$ systems are based on the values given in Table 3 and the Refs listed there. ${ }^{73,74}$ The vertical dotted lines emphasize the stability differences to the reference lines, $\log \Delta_{\mathrm{M} / \mathrm{pUpU}}$ and $\log \Delta_{\mathrm{M} / \mathrm{pUp}} \mathrm{P}_{\mathrm{S})} \mathrm{U}$ [defined in analogy to Eq. (3)], for the $\mathrm{M}(\mathrm{pUpU})^{-}$and $\mathrm{M}\left(\mathrm{pUp}(\mathrm{s}) \mathrm{U}^{-}\right.$complexes. For comparison of the thio effects the data for the $\mathrm{M}^{2+} / \mathrm{H}^{+} / \mathrm{UMPS}^{2-}$ and $\mathrm{M}^{2+} / \mathrm{H}^{+} / \mathrm{UMP}^{2-}$ systems (see Fig. 3) are also shown again. All plotted constants refer to aqueous solutions at $25^{\circ} \mathrm{C}$ and $I=0.1 \mathrm{M}\left(\mathrm{NaNO}_{3}\right)$. 


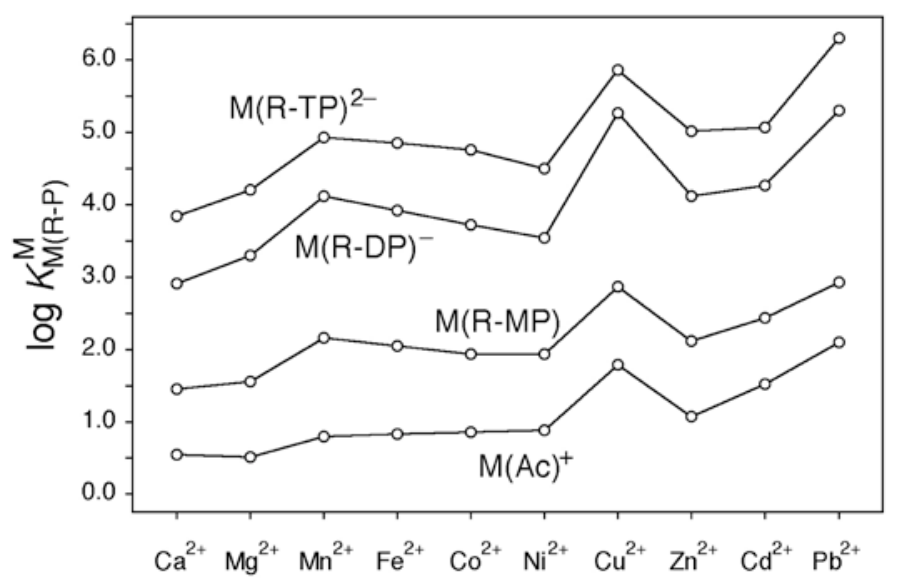

Figure 1 


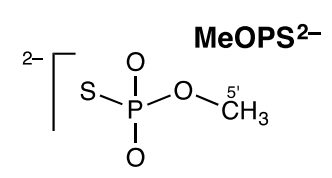

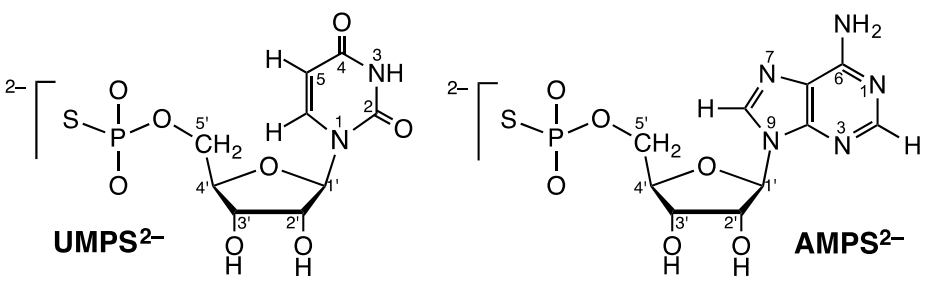

Figure 2 


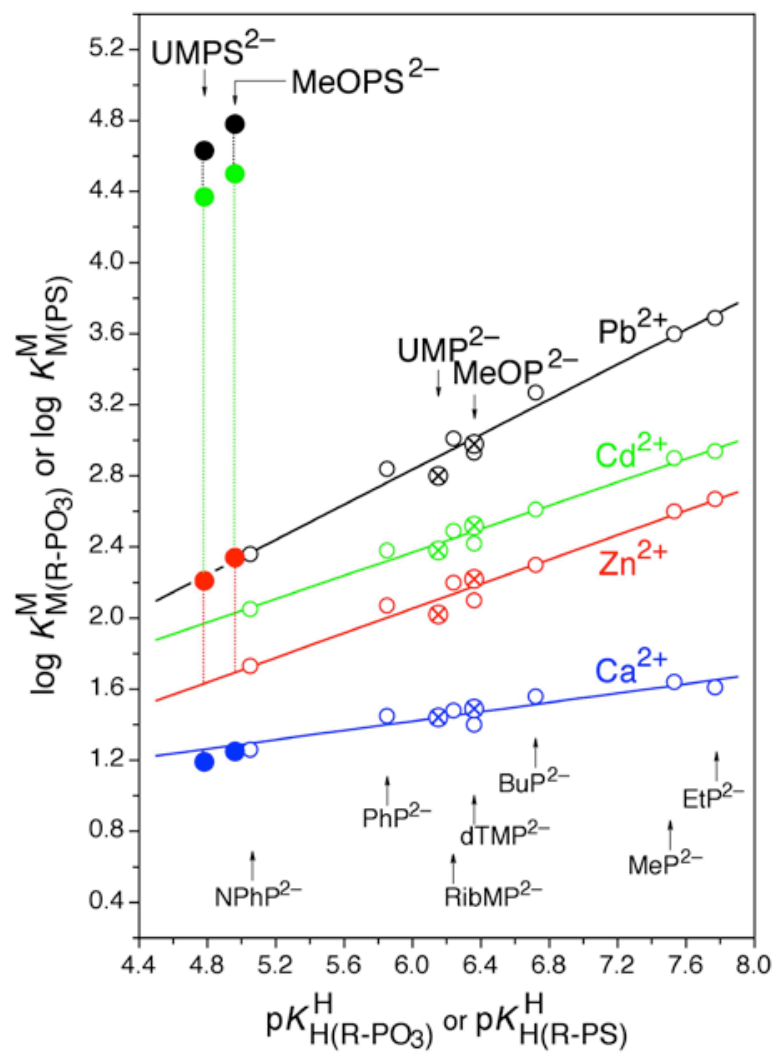

Figure 3 

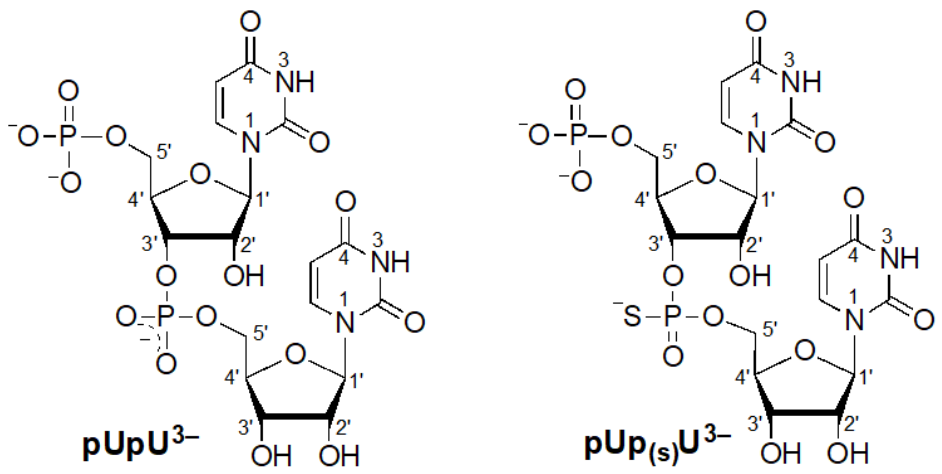

Figure 4 


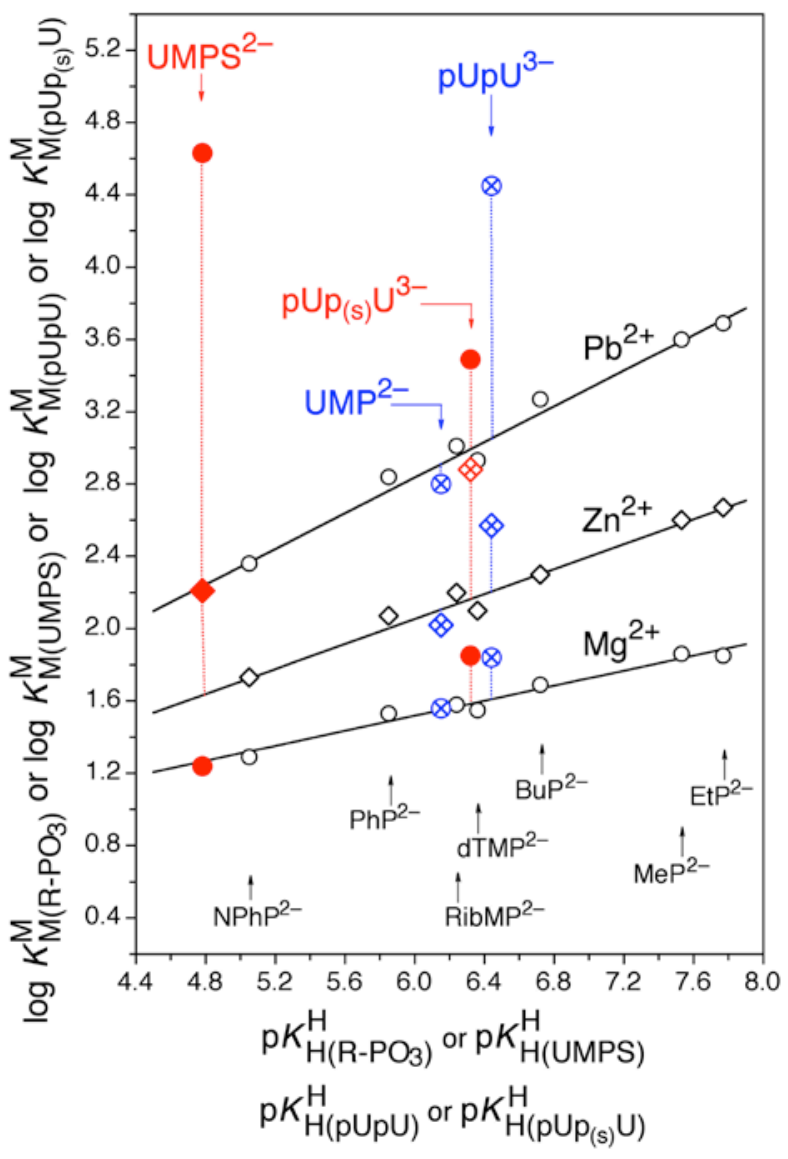

Figure 5 


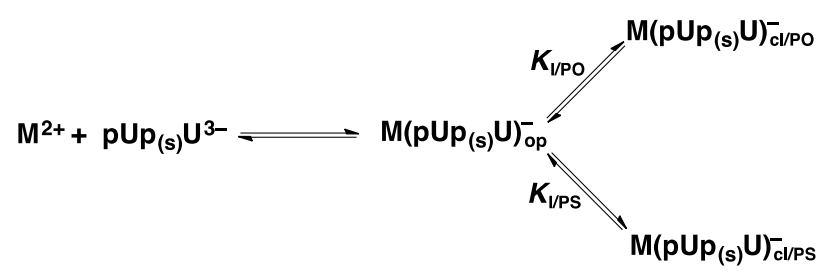

Equation 7 


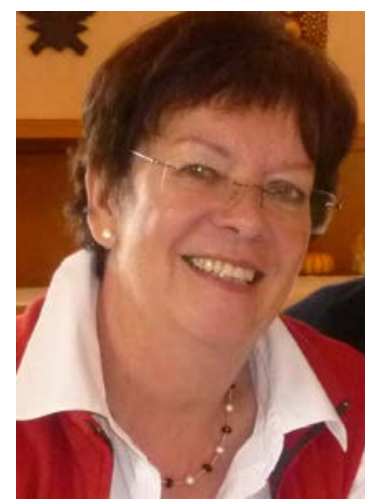

Astrid Sigel, at the University of Basel, has studied languages and is an editor of the Metal Ions in Biological Systems series (until Volume 44) as well as of the Sigels' new series Metal Ions in Life Sciences (since 2006; Volume 18 released in February 2018 by De Gruyter, Berlin). She has also co-edited the Handbooks on Toxicity of Inorganic Compounds (1988), on Metals in Clinical and Analytical Chemistry (1994; both with H. G. Seiler) and on Metalloproteins (2001; with Ivano Bertini) and she co-authored about 40 papers on topics in Bioinorganic Chemistry.

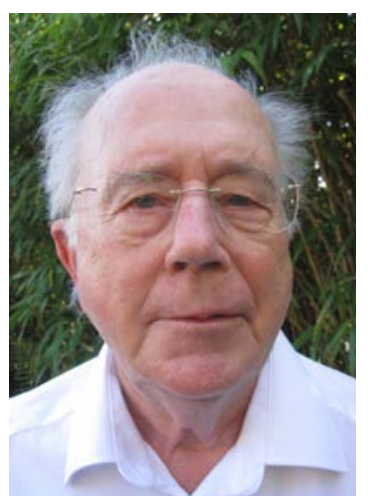

Bert P. Operschall graduated as a mechanical engineer from the Swiss Federal Institute of Technology, Zürich, Switzerland. He worked as a chemical engineer for Ciba Ltd., Ciba-Geigy Ltd., and Novartis Ltd.. After retiring from industry he discovered his interest in Bioinorganic Chemistry and joined the research group of Professor Helmut Sigel at the University of Basel in 2004; he co-authored about 30 publications.

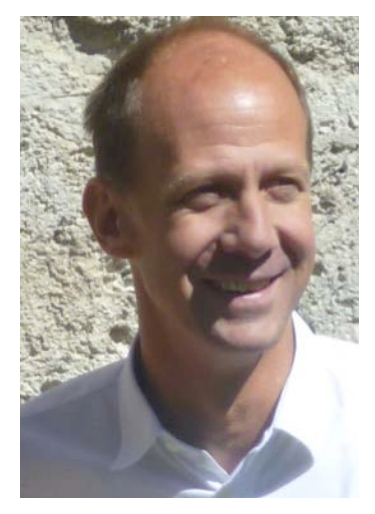

Roland K. O. Sigel is Full Professor (2016) of Chemistry at the University of Zürich (UZH), Switzerland and Dean of the Faculty of Science (2017). After his PhD (1999, University of Dortmund/Germany) and 3 years at Columbia University NY, he started as SNF-Assistant Professor at UZH (2003-2008) He received several prestigious fellowships, the EuroBIC Medal (2008), the Alfred Werner Prize (2009) and an ERC Starting Grant 2010. He is interested in the structural and functional role of metal ions in ribozymes and riboswitches, applying NMR, single molecule spectroscopy and further techniques. He is a co-editor of the MILS series. 


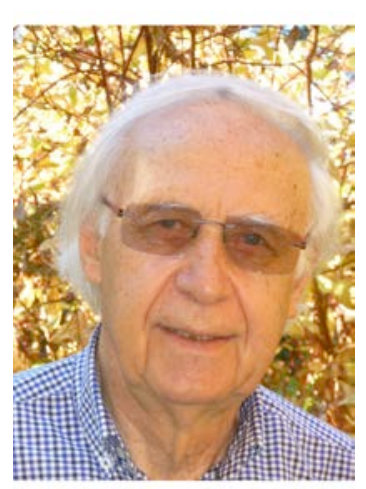

Helmut Sigel is Emeritus Professor (2003; University of Basel, Switzerland) with a long-standing interest in metal-bio-ligand interactions. He co-edited 65 books (see A.S.), published about 350 articles, and lectured worldwide. He was named Protagonist in Chemistry (ICA 339, 2002) and for his 80th birthday a Honorary Issue of JBIC (January 2018) pays tribute to his achievements.. He is a Honorary Fellow of the Indian Chemical Society and the Society of Biological Inorganic Chemistry. He received the P. Ray Award (Indian Chemical Society), the Werner Prize (Swiss Chemical Society), and a Doctor of Science honoris causa degree (Kalyani University, India). 


\section{Table of contents entry}

Graphic:
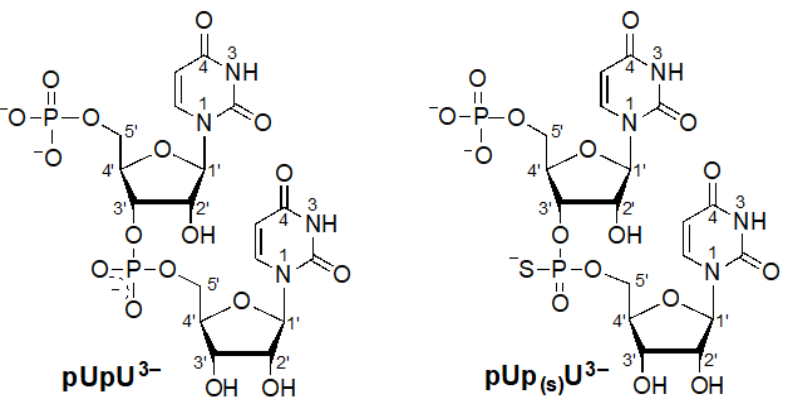

Text:

The lead(II)-lone pair leads to ambivalency: hemidirected (distorted, non-spherical) coordination spheres result from electronegative O-coordination and holodirected (symmetric, spherical) ones from less electronegative S-coordination. 